\title{
The negative influence and adverse outcome of blood transfusion in heart surgery patients
}

\author{
Volume 7 Issue 2 - 2016
}

\section{Editorial}

There is compelling evidence indicating that blood transfusion (BT) is excessive and sometimes unnecessary. Nearly 14 million units of blood are donated annually in the USA, and about 4million people receive BT every year. ${ }^{1,2}$ Blood transfusion administration in surgical and critical care settings varies between $30-100 \%$ of patients. On the other hand, blood donations have significantly diminished mainly because of decreasing number of qualified donors. ${ }^{3-6}$ This fact has resulted in a shortage of blood supply in blood banks worldwide which makes it necessary to seek out new treatment options. ${ }^{5}$ Although, alternatives to BT and other treatment options exist, they are seldom utilized.

Despite many technological improvements and therapeutic advances, open heart surgery is still associated with the risks of bleeding and thrombotic events. It is relatively frequent to observe a decrease in plasma hemoglobin values under $10 \mathrm{~g} / \mathrm{dL}$ in the immediate period after heart surgery. In this context, some patients would receive blood transfusion (BT), especially if there are clinical signs of decreased plasma volume. ${ }^{7-11}$ Although there is a clear evidence of change, since many decades ago it is believed that patients would benefit from a BT that increases the hemoglobin levels beyond $10 \mathrm{~g} /$ $\mathrm{dL}$ and the hematocrit levels beyond $30 \%$. There are several reasons to think this way. The transfused whole blood is an excellent plasma volume expander and stays in the intravascular space much longer than any other volume expander. Indeed, BT induces an increase in the plasma volume, a hemodynamic improvement, and an increase in the cardiac output and diuresis. Nevertheless, at the light of medicine based evidence, are these improvements correlated with decreased morbidity and lesser mortality?

Murphy et al., investigated the effects of BT in 8598 surgical patients during the post-operative period of coronary revascularization surgery. ${ }^{7}$ They found no benefit from blood transfusion for hematocrits as low as $21 \%$ (hemoglobin of $7 \mathrm{~g} / \mathrm{dL}$ ), and the risk of death within 30days of surgery was almost 6 times greater for patients who received blood. Moreover, red blood cell transfusion in these heart surgery patients was linked as an independent variable to an increase in infections and ischemic complications such as myocardial infarction, renal compromise and failure, and stroke. Additionally, transfused patients had prolonged mechanical ventilation, higher incidence of atrial fibrillation, longer hospital length of stay, and higher morbidity and mortality. ${ }^{7}$ Similar findings were demonstrated in several observational studies demonstrating clear association between red blood cell transfusion and adverse outcomes in cardiac surgery patients..$^{711}$ This adverse association between BT and cardiac surgery has been shown through the years in several studies and clinical observations. ${ }^{12-21}$ Indeed, Denton Cooley demonstrated similar findings almost four decades ago. ${ }^{16}$ It was also demonstrated that a single unit of red blood cell transfusion to a cardiac surgery patient is associated to a decreased survival at 10years after the BT. ${ }^{21}$

\author{
Osmar Antonio Centurion \\ Department of Health Sciences?s Investigation, Sanatorio \\ Metropolitano, Fernando de la Mora, Paraguay
}

\begin{abstract}
Correspondence: Osmar Antonio Centurión, Professor of Medicine, Asuncion National University, Department of Health Sciences $\square$ s Investigation, Sanatorio Metropolitano, Teniente Ettiene $215 \mathrm{c} /$ Ruta Mariscal Estigarribia, Fernando de la Mora, Paraguay, Email osmarcenturion@hotmail.com
\end{abstract}

Received: November 08, 2016 | Published: November 16, 2016

The Society of Thoracic Surgeons and the Society of Cardiovascular Anesthesiologists guidelines emphasize that the benefits of transfusion have not been adequately demonstrated and that existing evidence is an imperfect guide to transfusion decisions. They suggest a transfusion trigger of hemoglobin less than $7 \mathrm{~g} / \mathrm{dL}$ in postoperative cardiac surgery patients with a class IIa level of indication. ${ }^{20}$

There are certain possible mechanisms responsible for the increased ischemic complications with red blood cell transfusion in heart surgery patients. A pro-inflammatory effect and storage defects contribute to the adverse effect of BT. Stored red blood cells are known to have decreased 2,3 DPG in the cell membrane, hence, they are less deformable, less likely to deliver oxygen to the tissues, and with greater tendency to produce capillary obstruction. ${ }^{18}$ On the other hand, the mechanisms responsible for the increased incidence of infectious complications are due to the immunosuppressive effects of BT. Administration of blood products causes profound negative effects on the human immune system, a condition termed transfusionrelated immune modulation. Mechanisms for this immune modulation include suppression of cytotoxic cell and monocyte activity, release of immunosuppressive prostaglandins, inhibition of interleukin-2 production, and increase in suppressor T-cell activity. ${ }^{22-29}$ In addition, it is well known that BT was utilized against organ rejection in the beginnings of kidney transplantation in order to decrease the incidence of renal allograft rejection before effective immunosuppressant drugs became available. ${ }^{26}$ Moreover, BT has been associated with cancer recurrence and death in patients with malignancy. Although, the utilization of universal leukoreduction has been recommended to reduce the rate of febrile nonhemolytic transfusion reactions, the risk of viral transmission, and the unresponsiveness of platelet transfusion after previous alloimmunization, it does not appear to play a role in the risk for cancer recurrence in specific subsets of surgical patients. ${ }^{30}$

Therefore, unnecessary blood transfusions should be avoided to further reduce the risk for infection and other complications. Indeed, there is a clear medicine based evidence of the shortcomings of BT in the setting of heart surgery. The evidence that BT carries significant risks points out to avoid BT when possible. In this context, Rawn JD from Harvard Medical School stated that "the experience with 
Jehovah Witnesses demonstrates that when a commitment is made to avoid blood transfusion, the effort is successful in the vast majority of cases. Recognition that blood transfusion poses significant risk for what is frequently an uncertain benefit can inspire a similar level of commitment. ${ }^{21}$ ",

\section{Conclusion}

In conclusion, even one unit of blood transfusion during and immediately following heart surgery has been shown to be significantly associated with immediate and long-term adverse clinical outcomes, including increased infection, myocardial infarction, stroke, renal failure, prolonged ventilation and hospital stay, atrial fibrillation, multi-organ failure and death, as well as, increased overall healthcare costs. This is a serious call for attention to the medical community and a scientific motivation to perform a detailed and conscious revision of our routine daily medical practice.

\section{Acknowledgments}

None.

\section{Conflicts of interest}

Author declares there is no conflicts opf interest.

\section{Funding}

None.

\section{References}

1. Ratko TA, Cummings JP, Oberman HA, et al. Evidence-based recommendations for the use of WBC-reduced cellular blood components. Transfusion. 2001;41(10):1310-1319.

2. Goodnough LT, Brecher ME, Kanter MH, et al. Transfusion medicine. First of two parts-blood transfusion. NEnglJMed. 1999;340(6):438-447.

3. Mackenzie CF, Shander A. What to do if no blood is available but the patient is bleeding? South Afr J Anaesth Analg. 2008;14(1):39-43.

4. Bennett-Guerrero E, Zhao Y, O'Brien SM, et al. Variation in use of blood transfusion in coronary artery bypass graft surgery. JAMA 304(14): 1568-1575.

5. Sojka BN, Sojka P (2008) The blood donation experience: self-reported motives and obstacles for donating blood. Vox Sang . 2010;94(1):56-63.

6. Santos AA, Sousa AG, Piotto RF,et al. Mortality risk is dose-dependent on the number of packed red blood cell transfused after coronary artery bypass graft. Rev Bras Cir Cardiovasc. 2008;28(4):509-517.

7. Murphy GJ, Reeves BC, Rogers CA, et al. Increased mortality, postoperative morbidity, and cost after red blood cell transfusion in patients having cardiac surgery. Circulation. 2007;116(22):2544-2552.

8. Engoren MC, Habib RH, Zacharias A, et al. Effect of blood transfusion on long term survival after cardiac operation. Ann Thorac Surg. 2002;74(4):1180-1186.

9. Koch CG, Liang L, Duncan AI, et al. (Morbidity and mortality risk associated with red blood cell and blood component transfusion in isolated coronary artery by-pass grafting. Crit Care Med. 2006;34(6):1608-1616.

10. Murphy GJ, Angelini GD. Indication for blood transfusion in cardiac surgery. Ann Thorac Surg . 2006;82:2323-2334.

11. Koch CG, Li L, Van Wagoner DR, et al. Red cell transfusion is associated with an increased risk for post-operative atrial fibrillation. Ann Thorac Surg. 2006;82(5):1747-1756.
12. Surgenor SD, Defoe GR, Fillinger MP, et al. Intra-operative red blood cell transfusion during coronary artery by-pass graft surgery increases the risk of post-operative low-output heart failure. Circulation. 2006;114(1 Suppl):I43-I48.

13. Rao SV, Joilis JC, Harrington SA, et al. Relationship of blood transfusion and critical outcomes in patients with acute coronary syndromes. JAMA. 2004;292(13):1552-1562.

14. Herbert PC, Yetisir E, Martin C, et al. Is a low transfusion threshold safe in critically ill patients with cardiovascular diseases? Crit Care Med. 2001;29(2):227-234.

15. Defoe GR, Ross CS, Olmstead EA, et al. Lowest hematocrit on by-pass and adverse outcomes associated with coronary artery by-pass grafting. Ann Thorac Surg. 2001;71(3):769-776.

16. Ott DA, Cooley DA. Cardiovascular surgery in Jehovah's witnesses. Report of 542 operations without blood transfusion. JAMA. 1977;238(12):1256-1258.

17. Koch CG, Li L, Duncan AL, et al. Transfusion in coronary artery bypass grafting is associated with reduced long-term survival. Ann Thorac Surg. 2006;81(5):1650-1657.

18. Mathru M, Kleinman B, Blakeman B, et al. Myocardial metabolism and adptation during extreme hemodilution in humans after coronary revascularization. Crit Care Med. 1992;20(10):1420-1425.

19. Herbert PC, Wells G, Blajchman MA, et al. A multicenter randomized, controled clinical trial of transfusion requierements in critical care. $N$ Engl J Med. 1999;340(6):409-417.

20. Ferraris VA, Ferraris SP, Saha SP, et al. Peri-operative blood transfusion and blood conservation in cardiac surgery: The Society of Thoracic Surgeons and the Society of Cardiovascular Anesthesiologists clinical practice guidelines. Ann Thorac Surg. 2007;83(5 Suppl):S27-S86.

21. Rawn JD. Blood transfusion in cardiac surgery: A silent epidemic revisited. Circulation. 2007;116(22):2523-2524.

22. van Twuyver E, Mooijaart RJ, Ten Berge IJ, et al. Pre-transplantation blood transfusion revisited. N Engl J Med. 1991;325(17):1210-1213.

23. Jensen LS, Andersen AJ, Christiansen PM, et al. Postoperative infection and natural killer cell function following blood transfusion in patients undergoing elective colorectal surgery. Br J Surg. 1992;79(6):513-516.

24. Berezina TL, Zaets SB, Morgan C, et al. Influence of storage on red blood cell rheological properties. J Surg Res. 2002;102(1):6-12.

25. Vamvakas EC. Possible mechanisms of allogeneic blood transfusion-associated postoperative infection. Transfus Med Rev. 2002;16(2):144-160.

26. Opelz G, Terasaki PI. Improvement of kidney-graft survival with increased numbers of blood transfusions. $N$ Engl $\mathrm{J}$ Med. 1978;299(15):799-803.

27. Ganz ML, Wu N, Rawn J, et al. Clinical and economic outcomes associated with blood transfusions among elderly Americans following coronary artery bypass graft surgery requiring cardiopulmonary bypass. Blood Transfus. 2014;12(suppl 1):s90-s99.

28. Garraud O, Cognasse F, Tissot JD, et al. Improving platelet transfusion safety: biomedical and technical considerations. Blood Transfus. 2016;14(2):109-122.

29. Chen A, Trivedi AN, Jiang L, et al. Hospital Blood Transfusion Patterns During Major Noncardiac Surgery and Surgical Mortality. Medicine. 2015;94(32):-e1342.

30. Corwin HL, AuBuchon JP. Is leukoreduction of blood components for everyone? JAMA. 2003;289(15):1993-1955. 